\title{
The impact of operating conditions on component and electrode development for zinc-air flow batteries
}

\author{
Birgit Pichler ${ }^{1} \mathbb{C} \cdot$ Bernhard S. Berner $^{2} \cdot$ Nikolaus Rauch $^{1} \cdot$ Christian Zelger $^{2} \cdot$ Hans-Jürgen Pauling $^{3}$. \\ Bernhard Gollas $^{2} \cdot$ Viktor Hacker $^{1}$
}

Received: 5 April 2018 / Accepted: 1 July 2018 / Published online: 7 July 2018

(C) The Author(s) 2018

\begin{abstract}
Rechargeable zinc-air flow batteries are investigated as possible technology for fast responding large-scale electrical energy storage due to the use of inexpensive, non-toxic and abundant materials, and compact system design. The operating ranges for several parameters such as flow rate $\left(2-8 \mathrm{~cm} \mathrm{~s}^{-1}\right)$, concentration of electrolyte $(6$ or $8 \mathrm{M} \mathrm{KOH})$, charge/discharge current densities (up to $100 \mathrm{~mA} \mathrm{~cm}^{-2}$ mean), and active or passive air supply as well as their influence on the performance and stability of the electrodes are investigated and compared. Bi-catalyzed bifunctional air electrodes are tested by means of half-cell measurements achieving minimum 200 charge/discharge cycles at $50 \mathrm{~mA} \mathrm{~cm}{ }^{-2}$ with the longest operation time being $800 \mathrm{~h}$. At this current density, charge/discharge efficiencies are in the range of 50\% for all tested air electrodes. End-of-life characterization by means of scanning electron microscopy reveals mechanical degradation of the electrode material. On the negative zinc electrode, zinc deposition morphology on different current collector materials (nickel, brass, and steel) is investigated using Rota-Hull cylinders showing nickel to be the most suitable material. The pulse interrupt current method is thereby successfully applied for compact zinc deposition in a broad current density range without any electrolyte additive. Subsequent scale-up of the rechargeable zinc-air flow battery and unit cell operation is finally performed for proof-of-concept.
\end{abstract}

\section{Graphical Abstract}
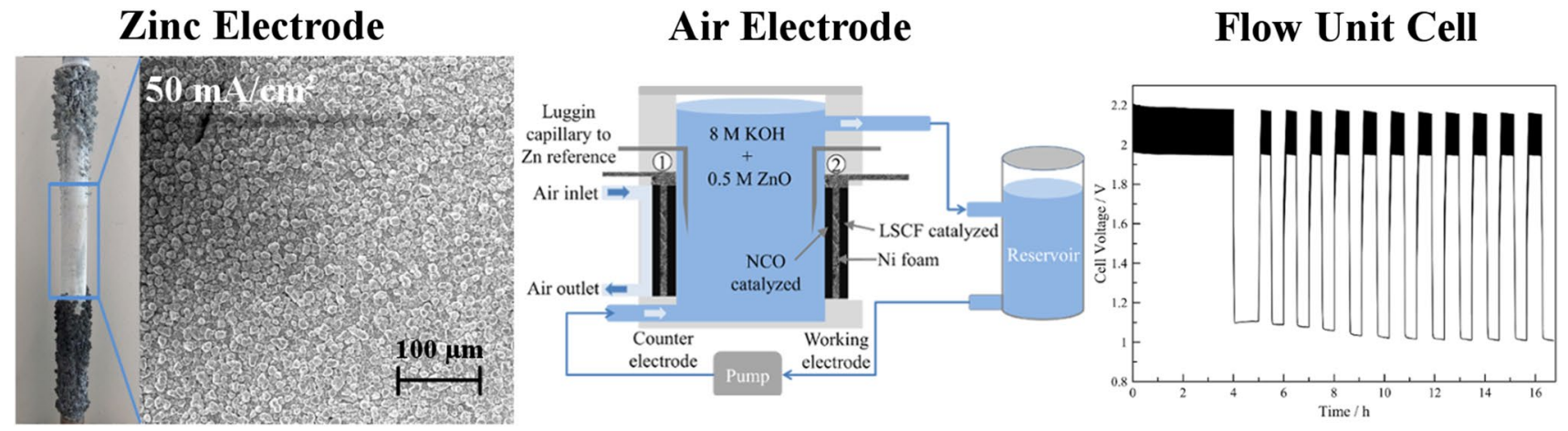

Keywords Zinc-air flow battery $\cdot$ Bifunctional air electrode $\cdot$ Pulse interrupt currents $\cdot$ Compact zinc morphology $\cdot$ Flow operation

Electronic supplementary material The online version of this article (https://doi.org/10.1007/s10800-018-1233-z) contains supplementary material, which is available to authorized users.

Birgit Pichler

birgit.pichler@tugraz.at

Extended author information available on the last page of the article

\section{Introduction}

Electrical energy storage (EES) with fast response times of below $1 \mathrm{~s}$ is crucial for balancing energy supply and demand from intermittent electricity generators such as wind and solar power systems. Secondary batteries are suited for 
this bridging power application with power ranging from $100 \mathrm{~kW}$ to $10 \mathrm{MW}$ [1-5] due to their ability to rapidly respond to load changes. In addition, because of low selfdischarge rates, the standby losses are small. However, in stationary units, high costs in comparison to the capacity, low energy density, and the negative ecological impact due to the use of scarce ( $\mathrm{Li}$-ion batteries) or toxic materials (i.e., lead-acid batteries, $\mathrm{NiCd}$ batteries) still prevent wide-spread installation of large-scale battery storage modules [1]. Also, for a competitive large-scale EES system, life-times of at least 10 years with about each $5 \mathrm{~h}$ charge and discharge per day are required [6].

Flow batteries allow deep discharge [4] and a higher flexibility concerning capacity and power using external tanks for storing the dissolved electroactive species [3, 7]. Therefore, the scale-up of a flow battery as stationary electrical energy storage system can be achieved in a cost-effective way [6]. Different zinc-based hybrid flow batteries have been developed during the last decades [3,7-9]. Among them is the most developed zinc-bromine flow battery, which was mainly researched during the 1980s with module storage capacities of up to $500 \mathrm{kWh}$ [3]. It is characterized by inexpensive materials and cycling efficiencies of about $75 \%[3$, 10]. Another type is the zinc-air flow battery $[9,11,12]$, which is investigated in this work and has already been demonstrated in varying forms in a few commercial and pilot systems (for example, US companies Fluidic Energy and EOS Energy Storage [13, 14], EU projects ZAESS and POWAIR [15-18]). Although the zinc-air flow battery is still far behind the development of the zinc-bromine system, it has the advantage to be free of potentially hazardous bromine species by substituting the positive electrode with a reversible air electrode. On this air electrode, oxygen from the surrounding air is reduced to hydroxide ions into the highly alkaline electrolyte during discharging and, reversely, oxygen is generated during charging (Table 1) [14, 15].

Although the high energy density of zinc-air batteries $[19,20]$ is less relevant in stationary flow systems, using a metal-air configuration can still significantly reduce the capital costs per $\mathrm{kWh}$ as only one active material has to be stored. Zinc is compared to lithium less hazardous and much more abundant, easily recyclable and thus less costly with only US \$2 per kg [14, 19]. Furthermore, no ion-exchange membrane is necessary to separate anolyte and catholyte [11]. The cost of a commercialized system is projected to be about US $\$ 160$ per $\mathrm{kWh}$ depending on the utilized air electrode catalysts [14]. Nevertheless, the zinc-air system suffers, as most metal-air batteries, from low roundtrip efficiencies of below $50 \%$ due to the sluggish oxygen reaction kinetics and short cycle life mainly caused by material degradation $[13,14,20]$. Not only material and catalyst selection for an optimal air electrode design plays a crucial role to overcome these issues but also the operating conditions have a significant impact on the longevity of the electrodes. This is also true for the zinc electrode, where mechanically unstable growth morphologies of zinc are commonly observed in current density ranges close to and far below the limiting current density [21]. The detachment of zinc particles from the electrode results in capacity losses, while the growth of zinc dendrites can lead to short circuits and damaging of the air electrode. It is thus essential to optimize and control the operating conditions of the zinc-air flow battery for the processes at both electrodes.

In this work, we show the influence of different operating conditions both on the long-term performance of bifunctional air electrodes as well as on the growth morphology of zinc on several current collector materials. The recharge capability of the zinc electrode is studied with pulse interrupt currents (PIC) on rotating electrodes in order to achieve dendrite-free zinc deposits [21, 22]. Concerning the positive electrode, of the many catalysts reported for zinc-air batteries [14, 23-26], well-known oxide catalysts-the $\mathrm{NiCo}_{2} \mathrm{O}_{4}$ spinel and the $\mathrm{La}_{0.6} \mathrm{Sr}_{0.4} \mathrm{Co}_{0.2} \mathrm{Fe}_{0.8} \mathrm{O}_{3}$ perovskite [27-30]were chosen and both employed in the investigated air electrodes. They bi-functionally catalyze the discharging reaction, i.e., oxygen reduction reaction-ORR, and the charging reaction, i.e., oxygen evolution reaction-OER. With such an air electrode, the system can be operated in a structurally more compact two-electrode arrangement with one zinc and only one air electrode, which reduces the complexity of the system compared to a three-electrode set-up [12, 16, 23]. Long-term operation of the air electrodes in half-cell set-up with minimum 200 charge/discharge cycles was performed at comparably high current densities of $50 \mathrm{~mA} \mathrm{~cm}^{-2}[3,14$, 31]. The investigated effects presented in this work concerning the air electrode are (i) the influence of charging with pulse interrupt currents (PIC), (ii) a comparison of open set-up to active gas supply, (iii) a test using an up-scaled electrode with $16 \mathrm{~cm}^{2}$ electrode size, (iv) a comparison of $6 \mathrm{M} \mathrm{KOH}$ electrolyte to $8 \mathrm{M} \mathrm{KOH}$, and (v) the influence of
Table 1 Electrochemical reactions in a zinc-air batterycharging reaction from left to right $[14,15]$

\begin{tabular}{lll}
\hline & Reaction & Potential vs SHE ${ }^{\mathrm{a}}(\mathrm{V})$ \\
\hline Zn electrode & $\mathrm{Zn}(\mathrm{OH})_{4}{ }^{2-}+2 \mathrm{e}^{-} \rightleftarrows \mathrm{Zn}+4 \mathrm{OH}^{-}$ & $\mathrm{E}_{00}=-1.26$ \\
Air electrode & $4 \mathrm{OH}^{-} \rightleftarrows \mathrm{O}_{2}+2 \mathrm{H}_{2} \mathrm{O}+4 \mathrm{e}^{-}$ & $\mathrm{E}_{00}=0.4$ \\
Overall reaction & $2 \mathrm{Zn}(\mathrm{OH})_{4}{ }^{2-} \rightleftarrows 2 \mathrm{Zn}+4 \mathrm{OH}^{-}+\mathrm{O}_{2}+2 \mathrm{H}_{2} \mathrm{O}$ & $\mathrm{E}_{\text {cell,eq }}=1.66$ \\
\hline
\end{tabular}

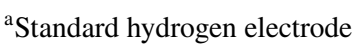


flowing electrolyte at different flow rates. The course of the potentials during discharging and charging as well as energy efficiency are used to characterize the stability of the electrodes. Finally, the gained knowledge on operation of both electrodes is applied in a full cell set-up with flowing electrolyte for demonstration. With these experiments, we hope to facilitate the assessment of optimal operating conditions and to take the zinc-air flow battery one step further from component development to full cell operation.

\section{Experimental}

\subsection{Rota-Hull and rotating cylinder experiments of the zinc anode}

Electrolytes were prepared with potassium hydroxide from Carl Roth $\mathrm{GmbH}(\geq 85 \%$, p. a.) and zinc oxide from SigmaAldrich ( $>99 \%$, puriss.). First, a solution with deionized water and $8 \mathrm{M}$ potassium hydroxide was prepared, and then different amounts of zinc oxide were dissolved to obtain zincate concentrations $c$ of 0.2 and $0.5 \mathrm{M}$.

The Rota-Hull cell (Eco Chemie B. V., Netherlands) has been described previously [21, 32] and consisted of a cylinder cathode and of a cylindrical platinized titanium mesh anode, placed concentrically around the cathode. Rota-Hull cell experiments were performed at 23 and $60{ }^{\circ} \mathrm{C}$ with a zincate concentration of $0.5 \mathrm{M}$. The rotational rates of the $\mathrm{RCH}$ cathodes are specified as linear velocities of the rotating cylinder surface $w\left[\mathrm{~cm} \mathrm{~s}^{-1}\right]$. Constant direct current was generated by the power and control unit of the Rota-Hull cell, while pulse current was fed into the Rota-Hull control unit from a PGSTAT128N (Metrohm Autolab B. V., Netherlands). Rotating cylinder experiments were carried out with a Pine Research Instruments Model AFMSRCE (USA) connected to the PGSTAT128N.

All cylinder electrodes in Rota-Hull experiments were $12 \mathrm{~cm}$ long with $6 \mathrm{~mm}$ diameter $l$ (exposed electrode area $\left.A=15 \mathrm{~cm}^{2}\right)$ from brass (CuZn39Pb3, Metrohm INULA $\mathrm{GmbH}$, Austria) or steel (C45 grade, material number 1.0503, Franz Grosschaedl Stahlgroßhandel GmbH, Austria). The nickel electrodes in rotating cylinder experiments were $1.00 \mathrm{~cm}$ long and had a diameter of $l=15 \mathrm{~mm}$ with an exposed electrode area $A=4.71 \mathrm{~cm}^{2}$. Nickel cylinders for Rota-Hull and rotating cylinder experiments were prepared by electrodepositing $10 \mu \mathrm{m}$ of $\mathrm{Ni}$ onto brass, copper, or steel cylinders from a sulfamate bath (Atotech, Germany) at a current density of $2.5 \mathrm{~A} \mathrm{dm}^{-2}$ and $50{ }^{\circ} \mathrm{C}$ under stirring. All brass and steel cylinders were pre-treated before zinc deposition. Brass was abraded with $\mathrm{SiC}$ grinding paper (800 mesh). Steel was treated first in aqueous $50 \mathrm{~g} \mathrm{~L}^{-1}$ UniClean 154 (Atotech, Germany) for $10 \mathrm{~min}$ at $65^{\circ} \mathrm{C}$ and then for $3 \mathrm{~min}$ in aqueous $120 \mathrm{~g} \mathrm{~L}^{-1}$ UniClean 675 (Atotech, Germany) at $70{ }^{\circ} \mathrm{C}$ under stirring.
Current efficiencies in the Rota-Hull experiments were calculated from the gravimetrically determined mass of zinc or in the case of the rotating cylinder experiments by coulometry of the potentiostatic zinc dissolution.

\subsection{Catalyst and air electrode preparation}

All chemicals were used as purchased without further purification. The synthesis procedure of $\mathrm{NiCO}_{2} \mathrm{O}_{4}$ spinel (NCO) supported on either untreated carbon nanofibers $(\mathrm{CNF})$ or nickel powder and the electrode manufacturing process using two different oxide catalysts has already been described in detail in a previous publication [27]. The procedure is shortly described in the following for electrode sizes up to $100 \mathrm{~cm}^{2}$.

$\mathrm{NiCo}_{2} \mathrm{O}_{4}$ spinel (NCO) was synthesized by an impregnation-calcination route by dissolving $\mathrm{Ni}\left(\mathrm{NO}_{3}\right)_{2} \cdot 6 \mathrm{H}_{2} \mathrm{O}$ (SigmaAldrich) and $\mathrm{Co}\left(\mathrm{NO}_{3}\right)_{2} \cdot 6 \mathrm{H}_{2} \mathrm{O}$ (Sigma-Aldrich) in the Ni:Co molar ratio of 1:2 in ultrapure water/2-propanol 1:1 (v:v). After addition of support material — either CNF (HTF150FFLHT, $150 \mathrm{~nm}$, lowheat; Electrovac AG, Austria) or nickel powder $(<50 \mu \mathrm{m}$, Sigma-Aldrich)—the dispersion was treated with ultrasounds for $1 \mathrm{~h}$. The solvent was evaporated under vigorous stirring at $80^{\circ} \mathrm{C}$. The dry powder was ground in a mortar and calcined at $375{ }^{\circ} \mathrm{C}$ for $2 \mathrm{~h}$ (air, heating rate $\left.5^{\circ} \mathrm{C} \mathrm{min}^{-1}\right)$. The final product was NCO/CNF ( 45 wt $\%$ on $\mathrm{CNF}$ ) and $30 \mathrm{wt} \% \mathrm{NCO} / \mathrm{Ni}$ powder. The second catalyst was a commercially acquired $\mathrm{La}_{0.6} \mathrm{Sr}_{0.4} \mathrm{Co}_{0.2} \mathrm{Fe}_{0.8} \mathrm{O}_{3}$ perovskite (LSCF, $\mathrm{d}_{50} 0.4-0.8 \mu \mathrm{m}, 10-14 \mathrm{~m}^{2} \mathrm{~g}^{-1}$; Sigma-Aldrich). To achieve a better distribution of the powder on CNF support, the perovskite was homogenously dispersed with CNF in a weight ratio of 3:1 in ultrapure water/2-propanol 1:1 (v:v) using an ultrasonic probe (LSCF/CNF).

For electrode manufacturing, two different electrode pastes were prepared by mixing the catalyst/support powders with PTFE (TF5032, suspension; Dyneon GmbH) in ultrapure water/2-propanol 1:1 (v:v). Paste one consisted of $50 \% \mathrm{NCO} / \mathrm{CNF}, 20 \% \mathrm{NCO} / \mathrm{Ni}$ powder, and $20 \% \mathrm{PTFE}$ (wt $\%$ ). The second paste comprised $80 \% \mathrm{LSCF} / \mathrm{CNF}$ and $20 \%$ PTFE (wt $\%$ ). The pastes were separately spread on opposite sides of nickel foam (pore size $450 \mu \mathrm{m}$, area density $420 \mathrm{~g} \mathrm{~m}^{-3}$, thickness $1.6 \mathrm{~mm}$; Alantum Corporation, Germany) using about 30-40 mg of the dry catalyst/support/PTFE mixture per $\mathrm{cm}^{2}$ of nickel foam. Nickel foam was chosen as current collector as it provides good electrical conductivity within the electrode and gives mechanical strength to the build. The catalyst loadings were $10 \mathrm{mg} \mathrm{cm}^{-2}$ $\mathrm{NiCo}_{2} \mathrm{O}_{4}$ and $25 \mathrm{mg} \mathrm{cm}{ }^{-2} \mathrm{La}_{0.6} \mathrm{Sr}_{0.4} \mathrm{Co}_{0.2} \mathrm{Fe}_{0.8} \mathrm{O}_{3}$.

\subsection{Electrochemical measurements of air electrodes and full cell}

Electrochemical characterization of the air electrodes in half-cell set-up was performed with a BaSyTec Cell Test 
System (Germany) in custom-made PMMA test cells with EPDM gaskets. Always two air electrodes were measured at the same time, one operated as working electrode and the second as counter electrode as depicted in Fig. 1. Both electrodes were separately referenced against a piece of zinc foil (1.6 $\mathrm{mm}, \sim 8 \mathrm{~cm}^{2}$ surface area; Alfa Aesar) via a Luggin capillary. The standard measurement was performed with $4 \mathrm{~cm}^{2}$ sized electrodes at room temperature $\left(24{ }^{\circ} \mathrm{C}\right)$ in $8 \mathrm{M}$ $\mathrm{KOH}$ with $0.5 \mathrm{M} \mathrm{ZnO}$ electrolyte and actively supplied with $25 \mathrm{~mL} \mathrm{~min}^{-1}$ synthetic air $\left(80 \% \mathrm{~N}_{2} / 20 \% \mathrm{O}_{2}\right)$ via the closed gas compartment. The gas exhaust was immersed in $5 \mathrm{~cm}$ of water to counter the hydrostatic pressure of the liquid electrolyte. The utilized electrode mounts were adapted to the different tests by increasing the electrode size from standard $4 \mathrm{~cm}^{2}$ to $16 \mathrm{~cm}^{2}$ or by removing the closed gas compartment for measuring with passive air supply. Furthermore, a DC centrifugal pump (WPDC-02.5L-1.00M-12-VP; Rotek, Austria) was added to the set-up for operation with flowing electrolyte. The surface flow velocities $w$ were 5, 6, and $8 \mathrm{~cm} \mathrm{~s}^{-1}$, which correspond in this set-up to $1.5,1.8$, and $2.1 \mathrm{~L} \mathrm{~min}^{-1}$. Long-term operation was performed with 2 $\mathrm{h}$ cycles consisting of $1 \mathrm{~h}$ discharge (ORR) and $1 \mathrm{~h}$ charging (OER). $1 \mathrm{~h}$ pulse charging with the PIC method was performed with $150 \mathrm{~mA} \mathrm{~cm}{ }^{-2}$ pulse for $t_{\mathrm{on}}=50 \mathrm{~ms}$ and no current for $150 \mathrm{~ms}$ (duty cycle $\gamma=0.33$ ), resulting in a mean current density $\left(j_{\mathrm{m}}\right)$ of $50 \mathrm{~mA} \mathrm{~cm}^{-2}$. Every hundred cycles ORR/OER polarization curves were recorded for additional information on the performance at lower current densities.

Full cell operation was demonstrated in a scaled-up setup with two $100 \mathrm{~cm}^{2}$ bifunctional air electrodes (overall $200 \mathrm{~cm}^{2}$ ) and with $100 \mathrm{~cm}^{2}$ of nickel foam (thickness $1 \mathrm{~mm}$ ) electrodeposited with zinc as negative electrode, which was mounted between the two air electrodes with $1 \mathrm{~cm}$ distance to each. The air electrodes were open to the ambient air with no active gas supply. The tank size was increased to $5 \mathrm{~L}$. A volume of $4.5 \mathrm{~L}$ of $6 \mathrm{M} \mathrm{KOH}$ electrolyte with $0.325 \mathrm{M} \mathrm{ZnO}$

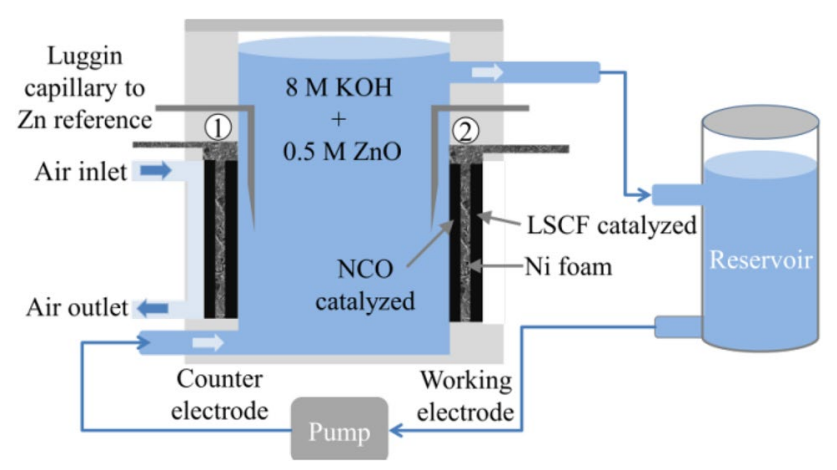

Fig. 1 Schematic drawing of the electrochemical measurement set-up for air electrode half-cell measurements depicting the closed set-up with active synthetic air supply (1) and the open set-up (2); images of the half-cell and full cell set-ups are shown in Supplementary Fig. S1 was pumped through the vertical cell with a surface flow velocity of $2 \mathrm{~cm} \mathrm{~s}^{-1}$, which corresponds to $1.9 \mathrm{~L} \mathrm{~min}^{-1}$. If $0.2 \mathrm{M}$ zinc is set as the minimum concentration, this cell configuration has a theoretical capacity of $30 \mathrm{Ah}$ [7]. The zinc electrodeposition was done by the PIC method for $4 \mathrm{~h}$ using $t_{\text {on }}=50 \mathrm{~ms}$ with $50 \mathrm{~mA} \mathrm{~cm}^{-2}$ and $50 \mathrm{~ms}$ pause (duty cycle $\gamma=0.5)$. This corresponds to a $j_{\mathrm{m}}$ of $25 \mathrm{~mA} \mathrm{~cm}^{-2}$ on the zinc electrode and $12.5 \mathrm{~mA} \mathrm{~cm}^{-2}$ at the air electrode. Approximately $12.2 \mathrm{~g}(0.19 \mathrm{~mol})$ of zinc was deposited during this time. The zinc-air cell was cycled with 35 min pulse charging with the same conditions as during the coating, followed by 30 min discharge at $25 \mathrm{~mA} \mathrm{~cm}^{-2}$ Zn electrode.

\subsection{Materials characterization}

A system VEGA3 ESEM Tescan 500 PA (Czech Republic) equipped with an energy dispersive $\mathrm{X}$-ray detector from Oxford Instruments (UK) was used for scanning electron microscopy and EDX. Prior to characterization by SEM, the air electrodes were thoroughly soaked with ultrapure water before drying preventing morphology changes by crystallizing $\mathrm{KOH}$.

\section{Results and discussion}

\subsection{Zinc electrode}

\subsubsection{Zinc morphology on different current collector materials with pulse interrupt current (PIC) plating}

A number of different growth morphologies have been reported for zinc electrodeposition from alkaline aqueous electrolytes [33]. They have been attributed to different current density regimes and range from filamentous mossy (nucleation and activation control) over compact morphologies such as layer-like (activation control) and boulder (mixed activation and diffusion control) to dendritic (diffusion control) and heavy spongy under mass-transport control (diffusion and convection resulting from hydrogen bubble stirring). In addition to the factors that govern the limiting current density during deposition (zincate concentration, convection, temperature), also the topography of the substrate surface and the crystallographic misfit of the substrate material to that of zinc have been reported to play a crucial role for the type of growth morphology. Three different zinc morphologies can be clearly distinguished on the Rota-Hull cylinder cathode in Fig. 2. Here, the zinc has been deposited by pulse interrupt current (PIC) for $100 \mathrm{~min}$ on nickel with an average current density $j_{\mathrm{m}}$ of $50 \mathrm{~mA} \mathrm{~cm}^{-2}$. At low current densities, the filamentous mossy morphology is observed, at medium current densities the compact boulder type, and at high current densities dendritic zinc. 

Rota-Hull cathode cylinder (Ni-coated brass) from $8 \mathrm{M}$ $\mathrm{KOH} / 0.5 \mathrm{M} \mathrm{ZnO}$ showing three distinct morphologies (bottom to top, low to high local current density): filamentous, compact, and dendritic. Deposition conditions were $T=60^{\circ} \mathrm{C}$, $w=3 \mathrm{~cm} \mathrm{~s}^{-1}, Q=300 \mathrm{C} \mathrm{cm}^{-2}$, $\gamma=0.33, t_{\text {on }}=50 \mathrm{~ms}$, $j_{\mathrm{m}}=50 \mathrm{~mA} \mathrm{~cm}^{-2}$
Fig. 2 Zinc deposited on a

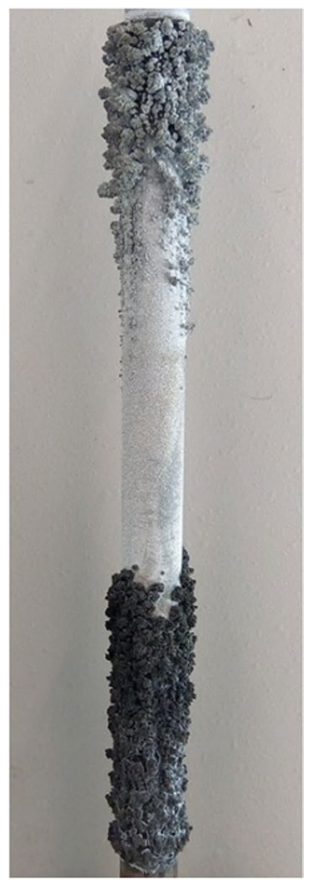

In order to test the impact of the substrate material and type of current, zinc was deposited for 15 min by PIC and by constant DC on brass, steel, and nickel with an average current density $j_{\mathrm{m}}$ of $33.33 \mathrm{~mA} \mathrm{~cm}{ }^{-2}$. All current efficiencies were in the range of 95-100\%. The resulting zinc morphologies are depicted schematically in Fig. 3. Most important, constant $\mathrm{DC}$ at $60^{\circ} \mathrm{C}$ produces the filamentous mossy morphology (denoted as $f$ in Fig. 3) almost irrelevant of the substrate material, while PIC leads to wide current density ranges with compact morphology (denoted as $c$ ). This is clear evidence for the beneficial effect of high pulse current densities on nucleation, meaning also high overpotentials. Slow and selective nucleation has been reported to result in mossy initiation [33]. At a temperature of $23{ }^{\circ} \mathrm{C}$, the results on nickel are slightly different. Clearly, the dendritic morphology is produced by PIC and constant DC already at considerably lower current densities compared to $60{ }^{\circ} \mathrm{C}$. This can be explained by the limiting current density, which decreases with temperature due to the increasing electrolyte viscosity and consequently a smaller zincate diffusion coefficient. Also the type of substrate material influences the current density boundaries between the different growth morphologies. At low current density, zinc deposits tend to grow at $<0001>$ (filamentous mossy). For steel, iron (110) is the bcc close-packed plane with an interatomic distance of $0.2482 \mathrm{~nm}$, which is smaller than the $0.2665-\mathrm{nm}$ distance of the zinc (0001) basal plane. This represents a larger negative misfit than those between zinc and fcc copper (111) with $0.2556 \mathrm{~nm}$. The negative misfit between zinc and nickel (111) with $0.2492 \mathrm{~nm}$ is similar to that between zinc and
Fig. 3 Morphologies of $\mathrm{Zn}(f$ filamentous mossy, $c$ compact, $c^{*}$ compact with few dendrites, $d$ dendritic) deposited with pulse interrupt current and conventional DC from $8 \mathrm{M}$ $\mathrm{KOH} / 0.5 \mathrm{M} \mathrm{ZnO}$ on brass, steel, and nickel Rota-Hull cylinders. Deposition conditions were $T=60{ }^{\circ} \mathrm{C}$ and $23{ }^{\circ} \mathrm{C}$, $t=15 \mathrm{~min}, \gamma=0.5, t_{\text {on }}=50 \mathrm{~ms}$, $j_{\mathrm{m}}=33.33 \mathrm{~mA} \mathrm{~cm}^{-2}$, and $w=6 \mathrm{~cm} \mathrm{~s}^{-1}$

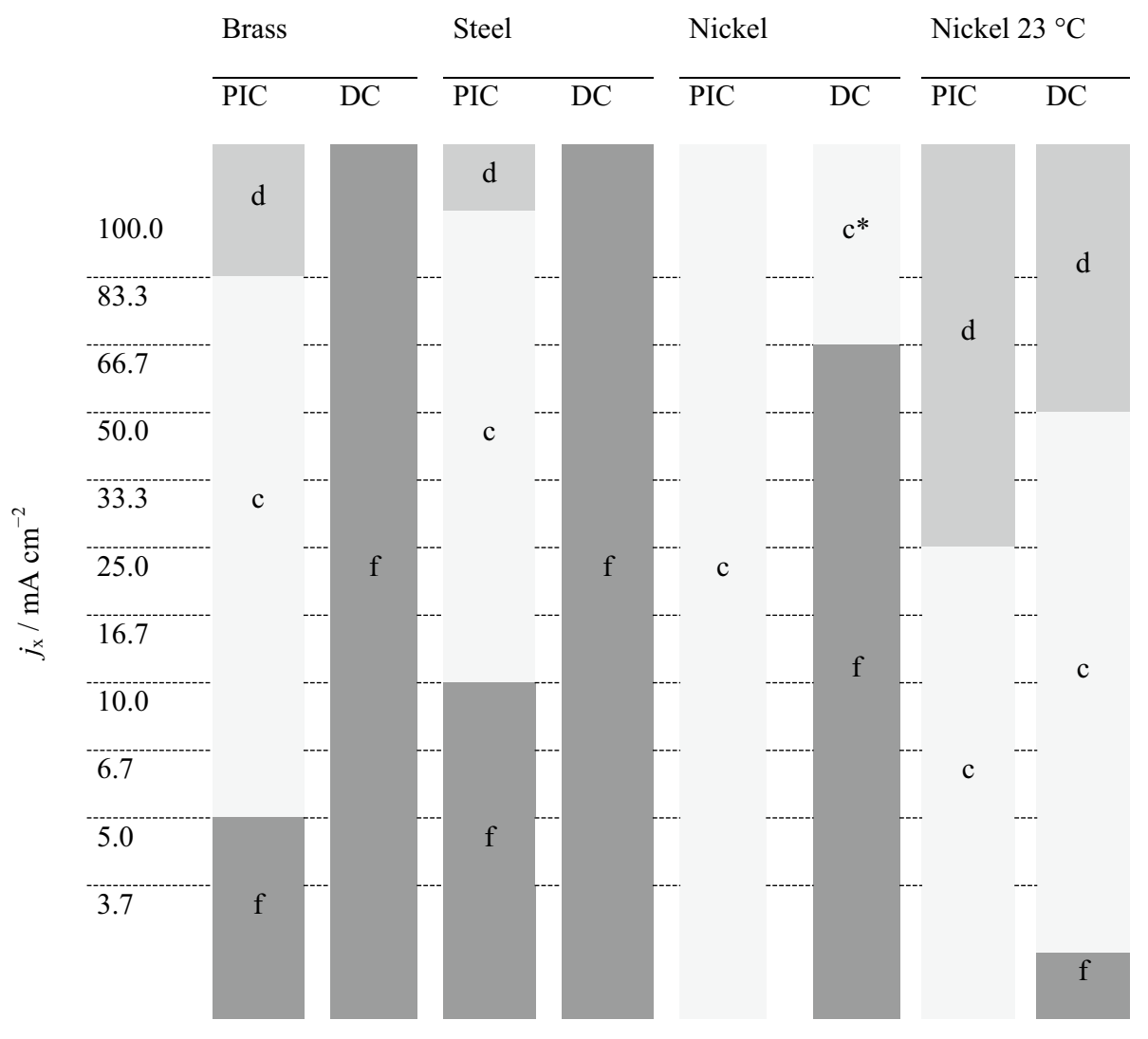


iron. In all cases, the negative misfits have been reported to result in the Volmer-Weber-type growth of 3D islands producing boulder, dendritic, or heavy spongy morphology [33]. The different growth behavior of $\mathrm{Zn}$ on brass, steel, and nickel must therefore be caused by something else. The local partial current density distribution of the hydrogen evolution side reaction depends on the respective overpotentials of the materials for this reaction. Presumably, the latter is lower for nickel. Consequently, a larger area towards the high local current density end of the nickel electrode is blocked for zinc deposition by hydrogen bubbles. This results in a shift of partial current density for zinc deposition towards the lower current density end of the electrode preventing the formation of the mossy morphology. It cannot be ruled out that slight differences in the surface roughness of the three substrates might affect the growth morphology as well. Based on the results obtained here, nickel seems to be the most suitable current collector material.

The local current densities shown along the length of the Rota-Hull cylinders are based on the primary current density distribution calculated from the geometry of the cell $[34,35]$. The practical current density distribution, which is affected also by the charge transfer kinetics and mass-transport limitations together with the resulting side reactions, might deviate significantly from the primary one. In order to verify that the morphology ranges observed along the RotaHull cylinder can be attributed to certain current density ranges, rotating cylinder experiments with defined current densities were carried out. The results are shown in Fig. 4. On the left-hand side is a picture of the Rota-Hull cylinder schematically shown in Fig. 3 (PIC zinc deposition on nickel at $60{ }^{\circ} \mathrm{C}$ ), where the compact boulder zinc morphology had been observed over the whole current density range. On the right-hand side, SEM images of zinc deposited on rotating cylinders at the indicated current densities under otherwise identical conditions are shown. The compact boulder-type zinc morphology could be reproduced at current densities of 50 and $60 \mathrm{~mA} \mathrm{~cm}^{-2}$. At $100 \mathrm{~mA} \mathrm{~cm}^{-2}$, the morphology still is boulder type, but the very coarse-grained pyramidal boulders are regarded as dendrite precursors. In all cases, the current efficiencies were in the range of $96-97 \%$.

Compact zinc has been described as a transient morphology in electrodeposition from alkaline electrolytes [36, 37]. After a certain deposition time with compact morphology, either mossy or dendritic growth is initiated. The consequence of this initiation time is also apparent from the results shown in Fig. 5. Zinc was electrodeposited by PIC in Rota-Hull cell experiments on brass and on nickel cylinders for periods of 15 and $150 \mathrm{~min}$ or 30 and $300 \mathrm{C} \mathrm{cm}^{-2}$, respectively. On both substrates, the range of local current densities with compact zinc based on the primary current density distribution is significantly narrower at longer deposition times and $60{ }^{\circ} \mathrm{C}$. The same effect is observed on nickel also

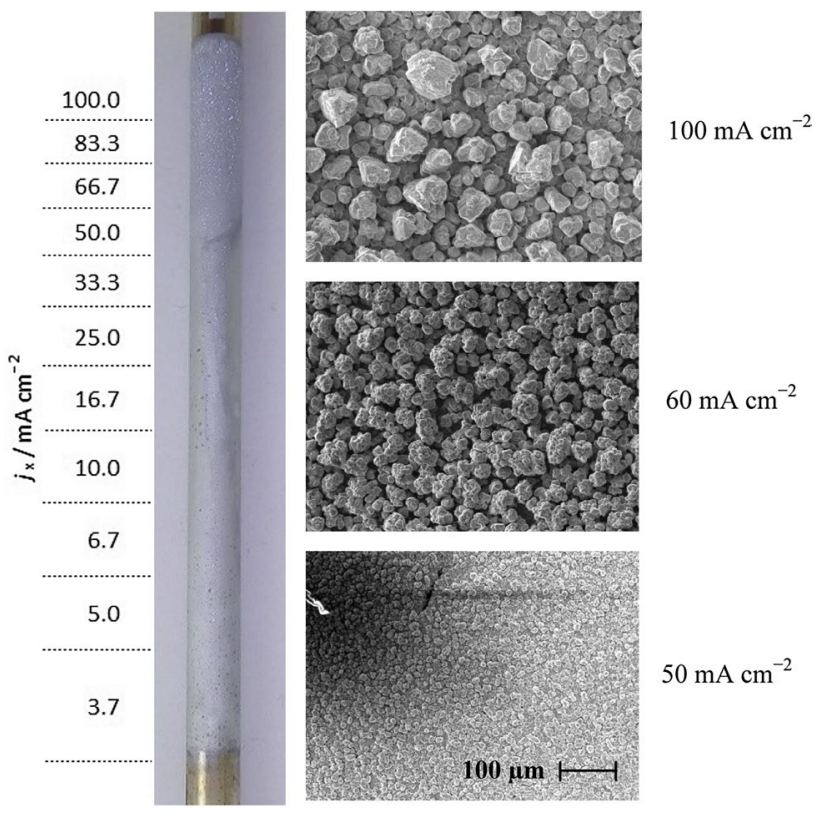

Fig. 4 Morphologies of $\mathrm{Zn}$ deposited on a Ni-coated Rota-Hull cathode cylinder from $8 \mathrm{M} \mathrm{KOH} / 0.5 \mathrm{M} \mathrm{ZnO}$ indicating the local current densities based on a primary current density distribution (left), and SEM images (500X) of $\mathrm{Zn}$ morphologies (right) deposited at defined current densities on Ni-coated cylinder electrodes under the same conditions $\left(T=60{ }^{\circ} \mathrm{C}, t=15 \mathrm{~min}, \gamma=0.5, t_{\text {on }}=50 \mathrm{~ms}\right.$, $j_{\mathrm{m}}=33.33 \mathrm{~mA} \mathrm{~cm}^{-2}$, and $w=6 \mathrm{~cm} \mathrm{~s}^{-1}$ )

for an electrolyte temperature of $23^{\circ} \mathrm{C}$. Again, the dendritic morphology is produced already at significantly lower local current densities for short and long deposition times, due to the lower limiting current. The current efficiencies are lower for brass increasing with deposition time from 95 to $98 \%$ and higher for nickel, again increasing with deposition time from 97 to $99 \%$. This probably reflects the extent of hydrogen evolution decreasing in the order brass $>$ nickel $>$ zinc.

\subsubsection{Dissolution/deposition cycling experiments with PIC plating}

The growth behavior of zinc during deposition/dissolution cycling is critical for the operation of the zinc-air flow battery. This behavior was tested with PIC deposition (charging) at 50,60 , and $70 \mathrm{~mA} \mathrm{~cm}{ }^{-2}$ average current densities and constant DC dissolution (discharging) at 100,120, and $140 \mathrm{~mA} \mathrm{~cm}^{-2}$ under turbulent flow conditions on nickel rotating cylinder electrodes as shown in Fig. 6. After 1000 $\mathrm{s}$ of PIC zinc deposition followed by 4 cycles of $100 \mathrm{~s}$ constant DC dissolution/200 s PIC deposition, compact zinc was still observed for 50 and $60 \mathrm{~mA} \mathrm{~cm}{ }^{-2}$ average current densities, while dendritic zinc had grown at $70 \mathrm{~mA} \mathrm{~cm} \mathrm{~cm}^{-2}$ average current density. The diffusion limiting current $j_{\text {lim }}$ for the rotating cylinder electrodes under these conditions is 
Fig. 5 Morphologies of $\mathrm{Zn}$ long- (150 $\mathrm{min})$ and short-term (15 min) deposited on brass and Ni-coated brass Rota-Hull cylinders from $8 \mathrm{M} \mathrm{KOH} / 0.5 \mathrm{M}$ $\mathrm{ZnO}$ with $T=60^{\circ} \mathrm{C}$ and $23{ }^{\circ} \mathrm{C}$, $w=6 \mathrm{~cm} \mathrm{~s}^{-1}, t_{\text {on }}=50 \mathrm{~ms}$, $\gamma=0.5, j_{\mathrm{m}}=33.33 \mathrm{~mA} \mathrm{~cm}^{-2}$

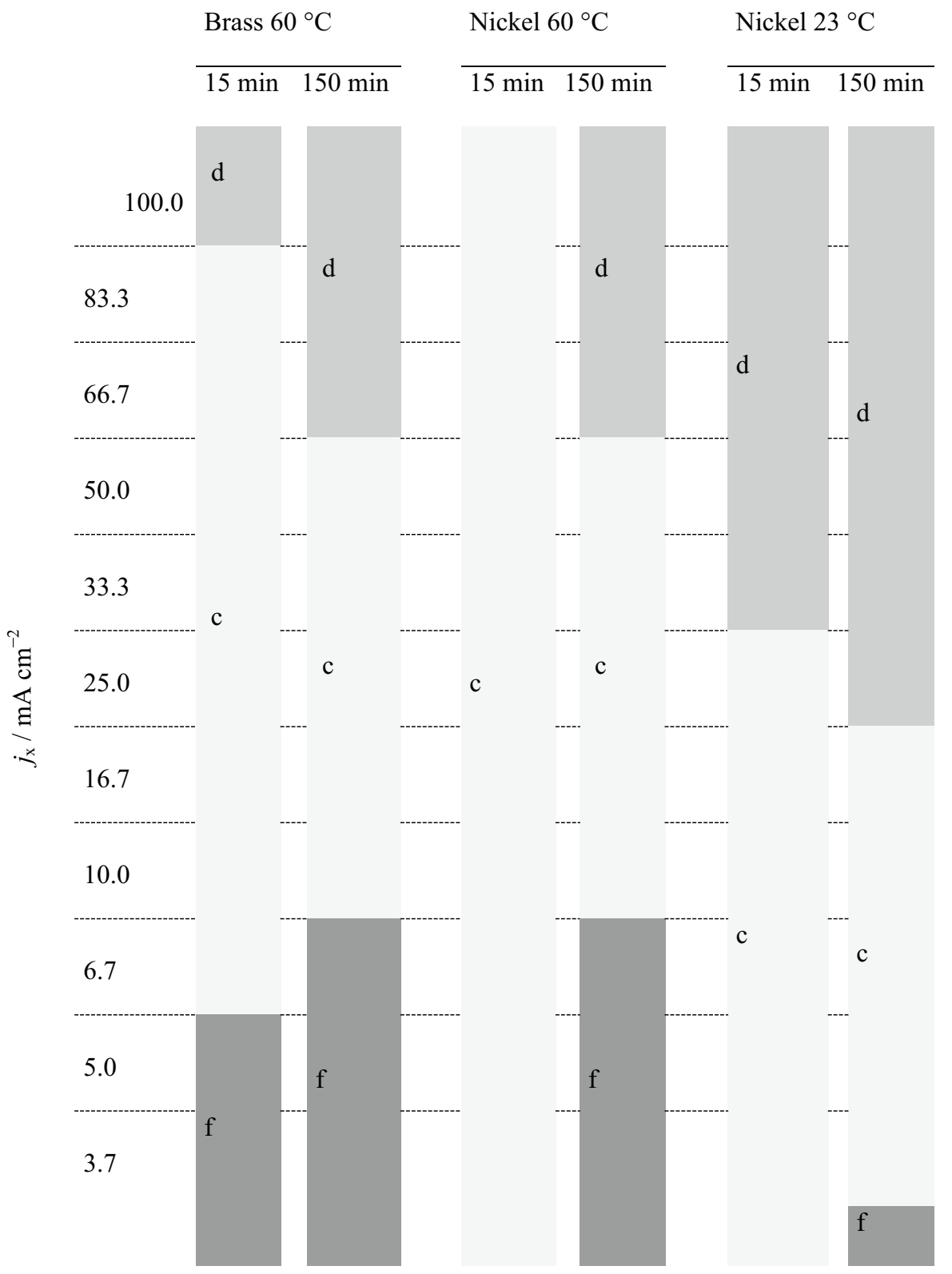

$52.7 \mathrm{~mA} \mathrm{~cm}^{-2}$ and can be calculated from Eq. 1 [32]. Here $n$ is the number of transferred electrons per zincate ion (2), $F$ is the Faraday constant $\left(96,485 \mathrm{C} \mathrm{mol}^{-1}\right), c$ is the zincate concentration $(0.5 \mathrm{M}), l$ is the cylinder diameter $(11.3 \mathrm{~mm})$, $v$ is the kinematic viscosity $\left(9.625 \times 10^{-3} \mathrm{~cm}^{2} \mathrm{~s}^{-1}\right)$, and $\mathrm{D}$ the diffusion coefficient of the zincate ion $\left(6.38 \times 10^{-6} \mathrm{~cm}^{2} \mathrm{~s}^{-1}\right)$.

$j_{\text {lim }}=0.079 \times n \times F \times c \times l^{-0.3} \times v^{0.70} \times v_{\text {kin }}{ }^{-0.344} \times D^{0.644}$.

It is noteworthy that even for an average current density of $60 \mathrm{~mA} \mathrm{~cm}{ }^{-2}$, which is above the limiting current density, the compact zinc morphology has been obtained. The "cumulated" current efficiencies determined from amperometric dissolution of the final zinc deposit were $96 \%$ for
$50 \mathrm{~mA} \mathrm{~cm}^{-2}, 95 \%$ for $60 \mathrm{~mA} \mathrm{~cm}^{-2}$, and $94 \%$ for $70 \mathrm{~mA} \mathrm{~cm}^{-2}$ average deposition current density.

\subsection{Air electrode}

\subsubsection{PIC charging with active or passive air supply}

Charging with pulse interrupt currents (PIC) is a beneficial method for obtaining compact zinc morphologies during charging as described in Sect. 3.1. Thereby unfavorable morphologies such as dendritic or mossy leading to shorts and loss of active material are avoided [21]. However, the high pulse currents could lead to accelerated degradation at the air electrode due to a much more vigorous oxygen bubble formation during OER and higher oxidative potentials. 


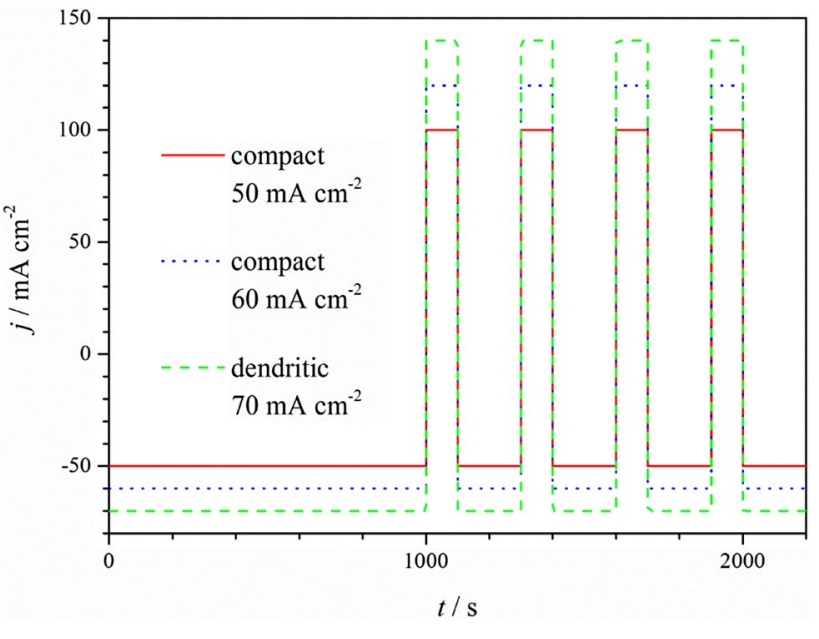

Fig. 6 Cycling scheme and resulting $\mathrm{Zn}$ morphologies on nickel rotating cylinders for $j_{\mathrm{m}}=50,60$, and $70 \mathrm{~mA} \mathrm{~cm} \mathrm{~cm}^{-2}$ pulse interrupt current charging and constant DC discharge currents in $8 \mathrm{M}$ $\mathrm{KOH} / 0.5 \mathrm{M} \mathrm{ZnO}$ with $T=60{ }^{\circ} \mathrm{C}, w=6 \mathrm{~cm} \mathrm{~s}^{-1}, t_{\mathrm{on}}=50 \mathrm{~ms}, \gamma=0.5$

In the following, air electrodes charged with the PIC method ( $\mathrm{E}_{\mathrm{PIC}}$ and $\left.\mathrm{E}_{\mathrm{PIC} \_ \text {open }}\right)$ are compared to the long-term behavior of an electrode charged with constant current $\left(\mathrm{E}_{\text {const }}\right)$ at $50 \mathrm{~mA} \mathrm{~cm}^{-2}$. The results of these half-cell measurements are depicted in Fig. 7.

$\mathrm{E}_{\text {const }}$ achieved $600 \mathrm{~h}$ (300 cycles) until the lower cutoff potential of $0.8 \mathrm{~V}$ vs $\mathrm{Zn} / \mathrm{Zn}^{2+}$ was reached. For 200 cycles, the potential difference between charge and discharge was below $1.0 \mathrm{~V}$. When charging with PIC, the electrode $\mathrm{E}_{\text {PIC }}$ could be operated for more than $800 \mathrm{~h} \mathrm{(380}$ cycles) and in the open set-up $\mathrm{E}_{\text {PIC_open }} 500 \mathrm{~h}$ ( 220 cycles) were achieved. Although the overall operation time varied significantly, all three electrodes showed nearly the same performance from 100 to $400 \mathrm{~h}$ indicating stable three-phase zones within the electrodes for ORR. The PIC method resulted in only slightly higher charging potentials of about $2.05 \mathrm{~V}$. The potential difference between pulse and pause increased from 101 to $176 \mathrm{mV}$ for $\mathrm{E}_{\mathrm{PIC}}$ and for $\mathrm{E}_{\text {PIC_open }}$ from 115 to $159 \mathrm{mV}$ over the course of the measurement. Overall, the maximum charging potentials were very stable for all three electrodes with the $\mathrm{E}_{\text {const }}$ exhibiting low OER potentials of about $1.94 \mathrm{~V}$.

The energy efficiency $[2,38,39]$ or roundtrip efficiency [24] for the air electrodes was calculated according to Eq. 2 with the applied current density $j$, the time $t$, and the measured potential $V$ at charge $c$ and discharge $d$, respectively.

Energy efficiency $[\%]=\frac{j_{\mathrm{d}} \times t_{\mathrm{d}} \times V_{\mathrm{d}}}{j_{\mathrm{c}} \times t_{\mathrm{c}} \times V_{\mathrm{c}}} \times 100$

Depending on the applied current densities, the roundtrip efficiencies of all three air electrodes are higher than $65 \%$ at $5 \mathrm{~mA} \mathrm{~cm}^{-2}$, about $60 \%$ at $20 \mathrm{~mA} \mathrm{~cm}^{-2}$ and in the range of $50 \%$ at $50 \mathrm{~mA} \mathrm{~cm}{ }^{-2}$ even after 200 cycles as summarized in Table 2. This is in agreement to reported values of other zinc-air battery systems [14, 28, 40-43]. The charge/discharge potentials are nearly the same for all
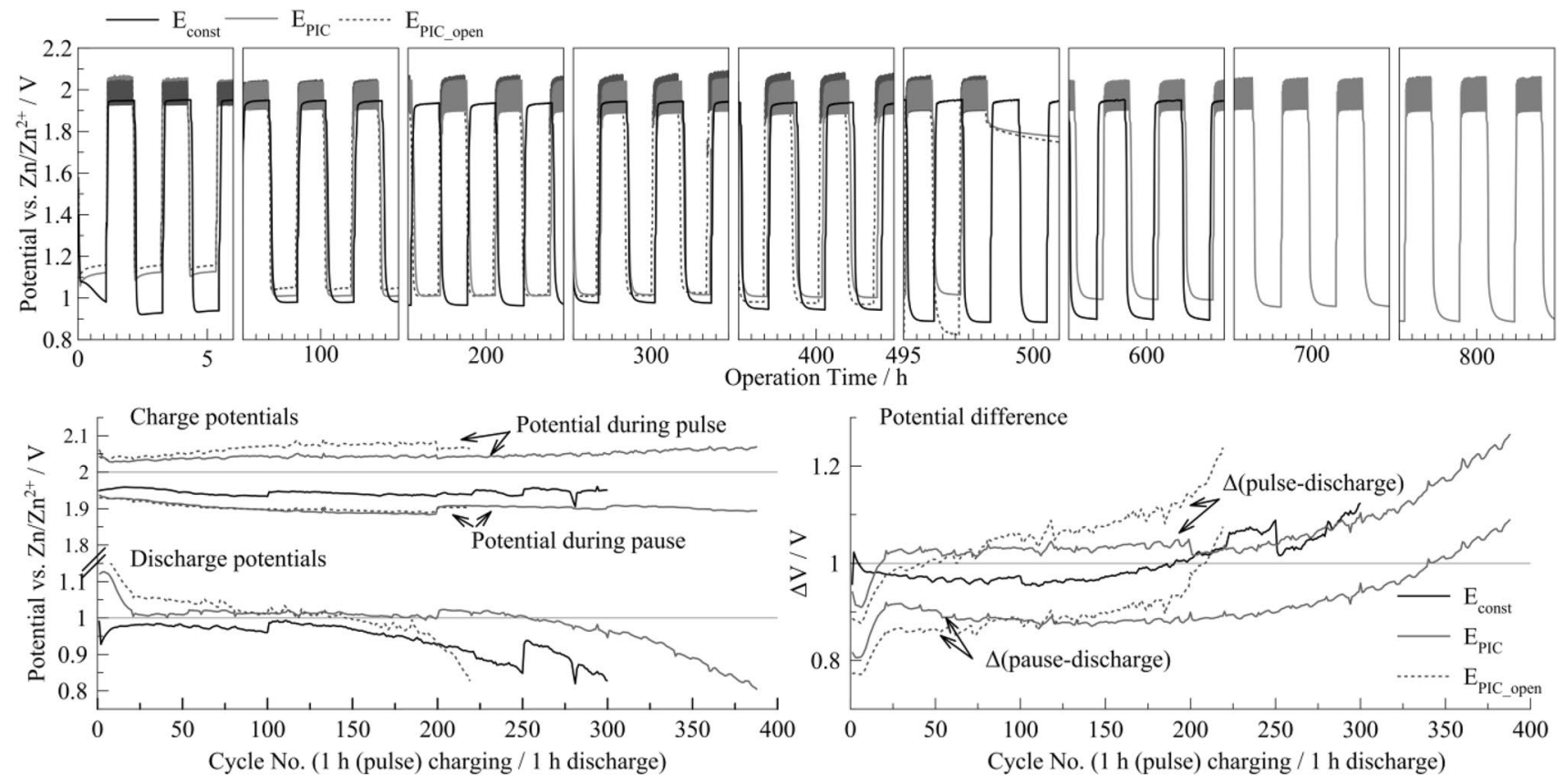

Fig. 7 Performance of three bifunctional air electrodes during long-term cycling operated at constant current density of $50 \mathrm{~mA} \mathrm{~cm}^{-2}\left(\mathrm{E}_{\mathrm{const}}\right)$ or charged with PIC method (pulsed charging at $50 \mathrm{~mA} \mathrm{~cm}^{-2}$ mean) with active synthetic air supply ( $\left.\mathrm{E}_{\mathrm{PIC}}\right)$ or open to ambient air ( $\mathrm{E}_{\mathrm{PIC} \_ \text {open }}$ ) 
three electrodes indicating that the PIC method is applicable in full cell operation without any harming effect on the air electrode. In fact, the $\mathrm{E}_{\text {PIC }}$ with active gas supply exhibited the highest performance after 200 cycles and the longest overall operation time.

Keeping stable three-phase boundaries for ORR within the electrode during repeated charging and discharging is one the most challenging issues in a rechargeable zinc-air battery, especially in connection with slow PTFE degradation and reduced hydrophobicity [14] (see Supplementary Fig. S3). As summarized by Pei et al. [16], several failure mechanisms are plausible. One is the slow flooding of the electrode caused by increasing penetration of electrolyte into the electrode's pore structure. In consequence, oxygen diffusion is hindered during ORR. This degradation mechanism is further enhanced through the charging reaction as the oxygen bubbles generated within the electrode during OER mechanically destroy the fine porous structure. The effect was observed with scanning electron microscopy (SEM) when comparing a fresh electrode to $\mathrm{E}_{\text {const }}$ and $\mathrm{E}_{\text {PIC_open }}$ after operation as depicted in Fig. 8. The surface of the electrodes is much rougher after the testing and the carbon fiber network appears washed out. The oxidative potentials during OER and the highly alkaline environment can lead to carbon corrosion [14] of the crude CNF indicated by a slightly orange-colored electrolyte observed after $100 \mathrm{~h}$ of testing. In general, the right selection of carbon support has a severe impact on the durability of bifunctional air electrodes [44, 45]. Furthermore, because of the constant synthetic air gas flow on the electrode's backside of $\mathrm{E}_{\text {const }}$ and $\mathrm{E}_{\mathrm{PIC}}$, a dryingout effect can occur leading to precipitation of $\mathrm{KOH}$ and $\mathrm{ZnO}$ within the pore structure. In consequence, sufficient gas supply is hindered during discharging. In comparison, the open set-up was more prone to leakage of electrolyte as no gas pressure could be applied. In consequence, fine droplets were visible on the electrode side facing the surrounding air after about $50 \mathrm{~h}$, which then formed a continuous film. However even with this film, the current-potential curves up to $50 \mathrm{~mA} \mathrm{~cm}^{-2}$ (depicted in Supplementary Fig. S2) showed no diffusion limitation. In the closed set-up with active gas flow, these electrolyte droplets were taken out with the air flow.

The results show that the favorable PIC method can be applied in a full zinc-air cell without damaging the air electrode. When comparing the open and the closed set-up, the

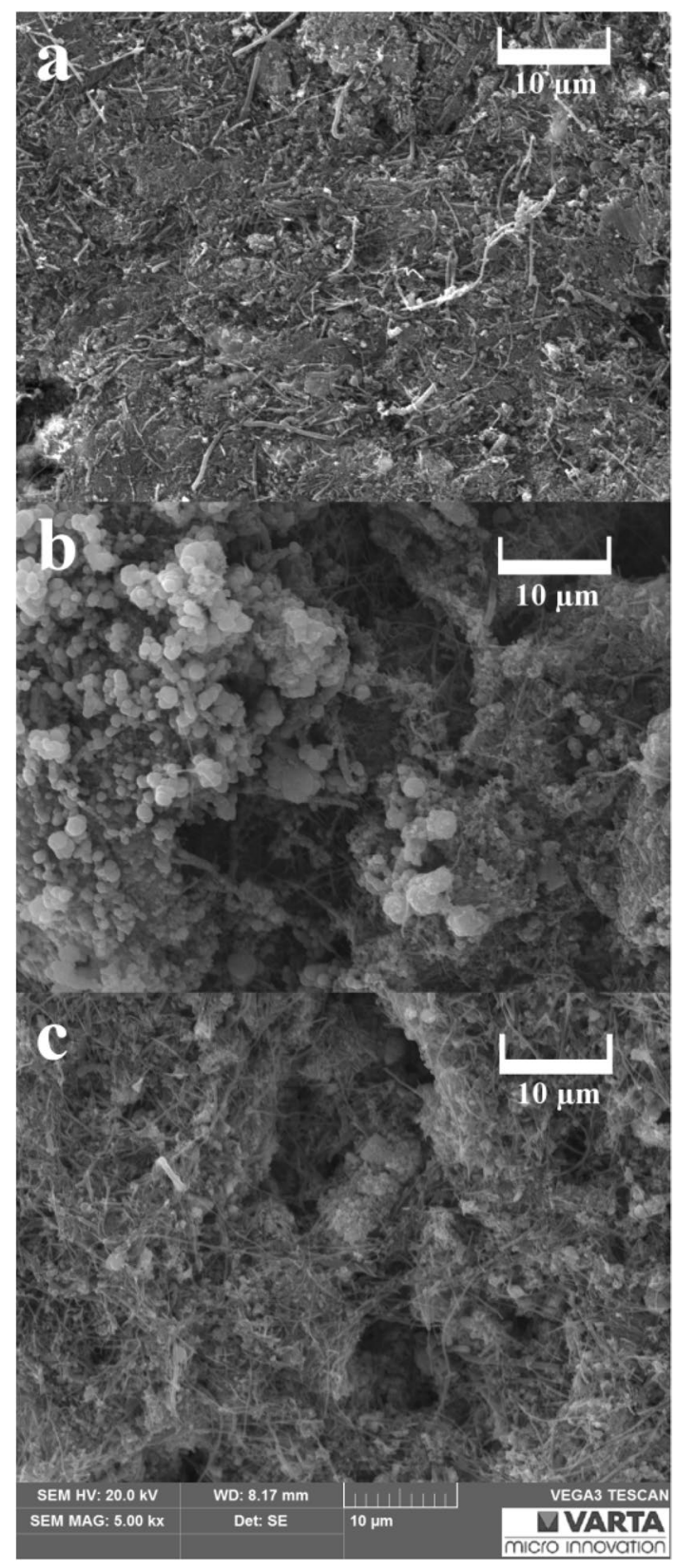

Fig. 8 SEM images of the NCO-catalyzed side facing the electrolyte during operation of $\mathbf{a}$ a fresh electrode before electrochemical characterization, $\mathbf{b}$ of $\mathrm{E}_{\text {const }}$ after operation, and $\mathbf{c} \mathrm{E}_{\mathrm{PIC} \_ \text {open }}$ after operation
Table 2 Charge/discharge potential differences and the calculated air electrode efficiencies from the recorded current-potential curves (see Supplementary Fig. S2) at the start of operation and after 200 cycles

\begin{tabular}{|c|c|c|c|c|c|c|}
\hline \multirow{2}{*}{$\begin{array}{l}\Delta V(V) \text { and } \\
\text { efficiency } \\
(\%)\end{array}$} & \multicolumn{2}{|c|}{ At $\pm 5 \mathrm{~mA} \mathrm{~cm}^{-2}$} & \multicolumn{2}{|c|}{ At $\pm 20 \mathrm{~mA} \mathrm{~cm}^{-2}$} & \multicolumn{2}{|c|}{ At $\pm 50 \mathrm{~mA} \mathrm{~cm}^{-2}$} \\
\hline & Start & After 200 cycles & Start & After 200 cycles & Start & After 200 cycles \\
\hline $\mathrm{E}_{\text {const }}$ & $0.61(68 \%)$ & $0.63(66 \%)$ & $0.71(63 \%)$ & $0.79(58 \%)$ & $0.83(58 \%)$ & $1.02(47 \%)$ \\
\hline $\mathrm{E}_{\mathrm{PIC}}$ & $0.65(66 \%)$ & $0.61(67 \%)$ & $0.78(60 \%)$ & $0.76(60 \%)$ & $0.95(53 \%)$ & $0.96(51 \%)$ \\
\hline $\mathrm{E}_{\mathrm{PIC} \text { open }}$ & $0.64(67 \%)$ & $0.61(67 \%)$ & $0.75(62 \%)$ & $0.78(59 \%)$ & $0.87(56 \%)$ & $1.03(48 \%)$ \\
\hline
\end{tabular}


closed set-up results in prolonged operation times, due to more control of the wetting behavior by varying the air flow or by increasing the air pressure. However, the system has to be designed in a more complex way than the open set-up. Nevertheless, when considering the need of scale-up, active air supply can be helpful to achieve even current distribution over the whole electrode area during operation. This can further be enhanced by implementation of flow fields as used in fuel cells.

\subsubsection{Scale-up to $16 \mathrm{~cm}^{2}$}

Although high activities and good stabilities for zinc-air cells have been reported by many groups [12, 46, 47], the usual active surface areas of tested air electrodes are smaller than $5 \mathrm{~cm}^{2}$. However, for stationary large-scale applications scale-up of the electrode size is crucial. This includes not only the scalability of the electrode production process but also the stability of these electrodes. During operation, the fine balance of gas accessibility and electrolyte permeability is altered due to the increased hydrostatic pressure. The long-term measurement of a $16 \mathrm{~cm}^{2}$ sized electrode, i.e., four times bigger surface area than $\mathrm{E}_{\text {const, }}$, with active synthetic air supply is depicted in Fig. 9. The ORR/OER roundtrip efficiency of $\mathrm{E}_{16} \mathrm{~cm}^{2}$ was $54 \%$ after 40 cycles at $30 \mathrm{~mA} \mathrm{~cm}^{-2}(\Delta \mathrm{V}=0.90 \mathrm{~V})$. In consequence to the increasing performance over time indicating improved wetting of the electrode, the current density was raised to $50 \mathrm{~mA} \mathrm{~cm}^{-2}$ after $100 \mathrm{~h}$ total operation time as shown in Fig. 9. In the first cycle at $50 \mathrm{~mA} \mathrm{~cm}^{-2}$ the efficiency was $51 \%$, and even $52 \%$ after $400 \mathrm{~h}$ total testing time and after changing to $6 \mathrm{M}$ $\mathrm{KOH}$ electrolyte. The change of electrolyte had no significant effect on the performance of the air electrode. Between 6 and $8 \mathrm{M}$, the ionic conductivity of $\mathrm{KOH}$ electrolyte is high with its maximum of $650 \mathrm{mS} \mathrm{cm}{ }^{-1}\left(25^{\circ} \mathrm{C}\right)$ at a concentration of $7 \mathrm{M}$ (or $\sim 30 \mathrm{wt} \% \mathrm{KOH}$ ) [13, 48]. Although even higher molarities would allow to dissolve more $\mathrm{ZnO}$ (i.e., about $1.2 \mathrm{M} \mathrm{ZnO}$ in $12 \mathrm{M} \mathrm{KOH}$ at room temperature) and thus increase the volumetric energy density of the flow battery system, the resulting increase of viscosity and corrosiveness would further complicate the system management $[15,19,48]$.

After total 200 cycles (517 h operation time), the efficiency was still $51 \%(\Delta \mathrm{V}=0.95 \mathrm{~V})$ at $50 \mathrm{~mA} \mathrm{~cm}{ }^{-2}$. The measurement was stopped due to increased leakage of electrolyte and too low ORR potentials after 280 charge/ discharge cycles. Overall, the performances of $\mathrm{E}_{16} \mathrm{~cm}^{2}$ and $\mathrm{E}_{\text {const }}$ are nearly the same showing that the scale-up from 4 to $16 \mathrm{~cm}^{2}$ was successfully achieved.

\subsubsection{Flowing electrolyte}

Because of the high flow velocities necessary for obtaining compact zinc morphologies, a $4 \mathrm{~cm}^{2}$ air electrode ( $\mathrm{E}_{\text {flow }}$ ) was long-term cycled with surface flow velocities up to $8 \mathrm{~cm} \mathrm{~s}^{-1}$ (which corresponds to $2.1 \mathrm{~L} \mathrm{~min}^{-1}$ with this cell geometry). The measurement is depicted in Fig. 10 showing the first $15 \mathrm{~h}$ of testing in the left graph and the following $400 \mathrm{~h}$, i.e., overall 200 cycles at $8 \mathrm{~cm} \mathrm{~s}^{-1}$ on the right-hand graph. The lower operation time of $450 \mathrm{~h}$ compared to the other electrodes is caused by the longer shut-off times during the measurement of $\mathrm{E}_{\text {flow }}$. After every restart, the first ORR cycle exhibited low potentials; however, after the first charging the ORR potentials improved again indicating that the three-phase boundaries were restored. This effect indicates that during shut-off times the electrode soaked with $\mathrm{KOH}$, but the electrolyte was then displaced again by the generated oxygen during OER. Altogether, the $\mathrm{E}_{\text {flow }}$ electrode exhibited stable ORR and OER potentials for more than $400 \mathrm{~h}$, even with the high shear forces affecting the electrode's surface. In fact, the flowing electrolyte had the positive effect to remove the generated oxygen bubbles during OER resulting in more stable charging potentials as shown in Supplementary Fig. S4. Increase of flow velocity from 5 to $8 \mathrm{~cm} \mathrm{~s}^{-1}$ (i.e., $1.5-2.1 \mathrm{~L} \mathrm{~min}^{-1}$ ) did not affect the performance as can be seen in Fig. 10 (left) between 10 and $17 \mathrm{~h}$ of operation.

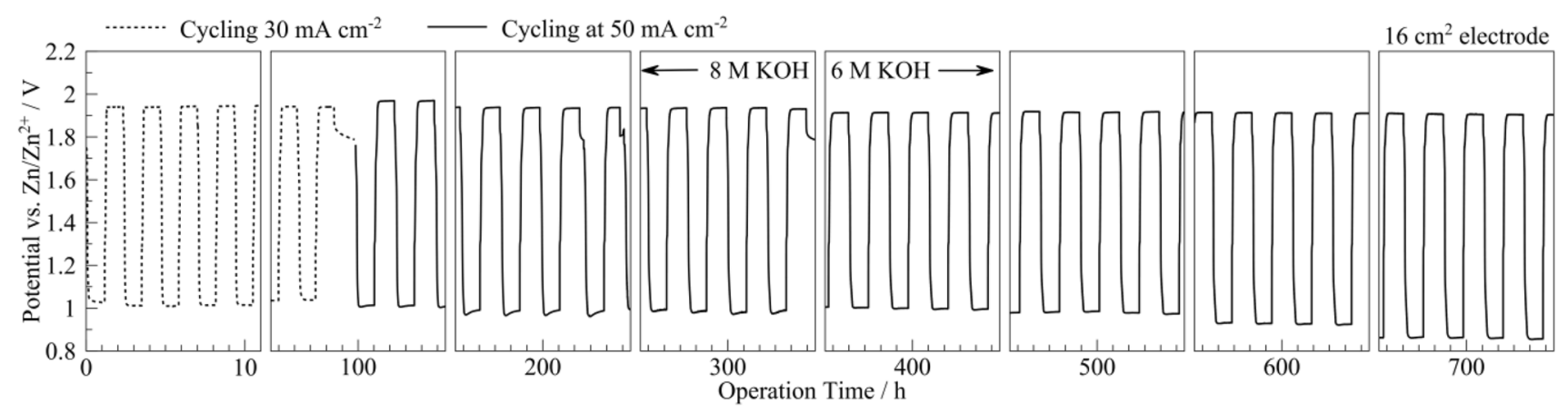

Fig. 9 Performance of a $16 \mathrm{~cm}^{2}$ bifunctional air electrode during long-term cycling operated at 30 and $50 \mathrm{~mA} \mathrm{~cm}$ in 8 or $6 \mathrm{M} \mathrm{KOH} \mathrm{electrolyte}$ (actively supplied with synthetic air) 

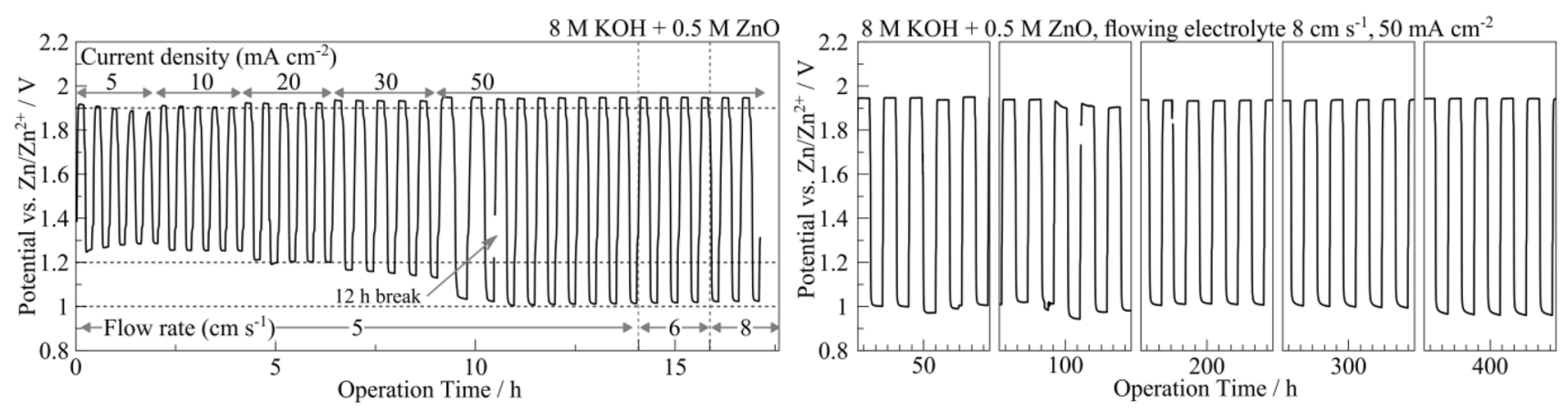

Fig. 10 Performance of a $4 \mathrm{~cm}^{2}$ bifunctional air electrode during long-term cycling with flowing electrolyte $\left(w=5-8 \mathrm{~cm} \mathrm{~s}{ }^{-1}\right.$, i.e. $1.5-$ $2.1 \mathrm{~L} \mathrm{~min}^{-1}$ ) and increasing current density up to $50 \mathrm{~mA} \mathrm{~cm}^{-2}$ (supplied with synthetic air)

This indicates that the fine Ni foam provides sufficient stability for the catalyst/CNF/PTFE network and that in this build slow material removal is prevented. The results show that the air electrode can withstand the stressing conditions (high surface flow velocities, PIC charging) needed for compact zinc deposition. Nevertheless, it has to be considered that too high flow velocities reduce the energy efficiency of the whole system due to the power needed for pumping $[49,50]$. The air electrode efficiency after $50 \mathrm{~h}$ of long-term operation was $50 \%, 52 \%$ after $200 \mathrm{~h}$, and still $50 \%$ after $400 \mathrm{~h}$ of operation. The measurement was stopped after $450 \mathrm{~h}$ due to increased electrolyte leakage.

After these promising results with pulse interrupt current charging for both the reversible air electrode and the zinc electrode, it was highly interesting to test the effect of PIC charging in the unit cell with flowing $\mathrm{KOH}$ electrolyte.

\subsection{Full cell operation with $100 \mathrm{~cm}^{2}$ air electrodes and zinc pulse interrupt current plating}

The first full cell operation at room temperature with flowing $6 \mathrm{M} \mathrm{KOH}$ electrolyte is shown in Fig. 11, depicting the unit cell voltage over time. After PIC deposition of zinc onto the nickel foam within the first $4 \mathrm{~h}$, the cell was cycled for $17 \mathrm{~h}$, showing stable charge cell voltages over the whole operation time and, after an initial decrease, also stable discharge voltages at $>1 \mathrm{~V}$. During the first full cycle, the efficiency of the complete zinc-air cell is $51 \%$ at $25 \mathrm{~mA} \mathrm{~cm}^{-2} \mathrm{Zn}$. This value includes, in contrast to the efficiencies listed in Table 2, also the ohmic resistances and the zinc overpotentials. However, these losses are much smaller in comparison to the ORR/ OER overpotentials [51]. At the last cycle, the efficiency was $47 \%$.

The results show that although the manufacturing of $100 \mathrm{~cm}^{2}$ air electrodes was successfully achieved, further optimization of the set-up is still necessary in order to prevent electrolyte leakage. The leakage posed a rather minor problem in small electrodes up to $16 \mathrm{~cm}^{2}$; however, the open set-up used for full cell operation in combination with the big air electrode surface area of $200 \mathrm{~cm}^{2}$ (cell height of $16 \mathrm{~cm}$ ) allowed too much loss of electrolyte so that the electrode could not be operated further. Suggestions for improvement would be the backing of the air electrodes with an additional PTFE layer or an additional gas diffusion layer
Fig. 11 Performance of a zinc-air flow unit cell with $100 \mathrm{~cm}^{2}$ zinc-coated nickel foam as negative electrode and two $100 \mathrm{~cm}^{2}$ sized bi-catalyzed bifunctional air electrodes open to the ambient air

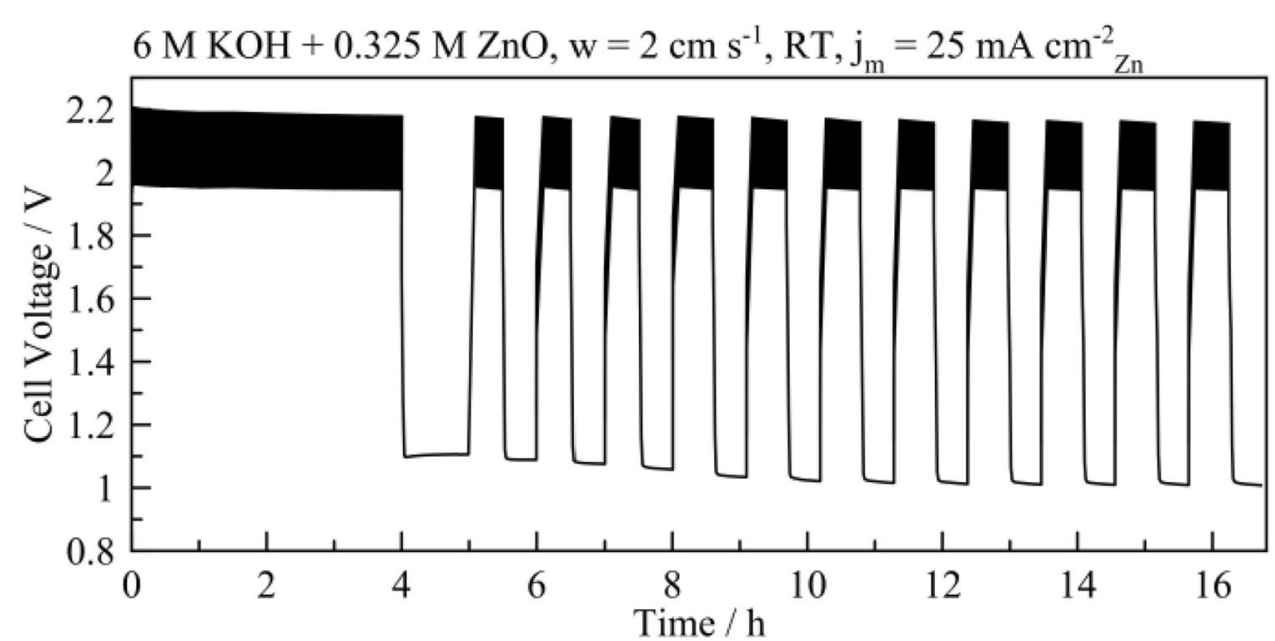


(GDL) as known from fuel cell technology [52]. By achieving this, the next step would be the increase of surface flow velocity from 2 to $6 \mathrm{~cm} \mathrm{~s}^{-1}$ by reducing the electrode distance. Nevertheless, this measurement can be seen as proofof-concept that the knowledge gained by the investigations on both electrodes can be applied for unit cell operation.

\section{Conclusion}

Separate study of the operating conditions of both half-cells in the rechargeable zinc-air flow battery allows faster transfer to larger-scaled full cells. In full cells often only the cell voltage is measured, which makes it more challenging to differentiate and attribute the various effects occurring at anode and cathode. Determining the operating range for various parameters allows further optimization of the cell performance. The investigated parameters discussed in this paper and their effects on the half- and full-cell performances are summarized as follows:

- In the range of $10-50 \mathrm{~mA} \mathrm{~cm}^{-2}$ average current density, compact zinc morphologies are obtained for pulse interrupt current (PIC) charging times as long as $150 \mathrm{~min}$ in additive-free $0.5 \mathrm{M} \mathrm{ZnO} / 8 \mathrm{M} \mathrm{KOH}$ at $60{ }^{\circ} \mathrm{C}$. At $23{ }^{\circ} \mathrm{C}$, the average current density producing compact zinc decreases to a range between 3.7 and $16.7 \mathrm{~mA} \mathrm{~cm}^{-2}$. Charge/discharge cycling using PIC results in compact dendrite-free zinc deposits up to $60 \mathrm{~mA} \mathrm{~cm}^{-2}$ mean current density $j_{\mathrm{m}}\left(120 \mathrm{~mA} \mathrm{~cm}^{-2}\right.$ pulse current density, flow rate $6 \mathrm{~cm} \mathrm{~s}^{-1}$, and $60^{\circ} \mathrm{C}$ ). Nickel is preferred over brass and stainless steel as substrate material in producing compact zinc deposits.

- On the air electrode, applying the PIC charging waveform, the charging potentials stay below $2.1 \mathrm{~V}$ even with pulse currents of $150 \mathrm{~mA} \mathrm{~cm}^{-2}$. Long-term results show that there is no accelerated degradation of the air electrode by that method [27].

- Scaling-up of the utilized manufacturing process was successful for electrode sizes up to $100 \mathrm{~cm}^{2}$. Up-scaling from 4 to $16 \mathrm{~cm}^{2}$ resulted in comparable operation times. For long-term operation of bigger sized electrodes, additional backing is required.

- 8 and $6 \mathrm{M} \mathrm{KOH}$ electrolytes are both suitable for operation of the flow cell.

- High electrolyte flow rates of up to $8 \mathrm{~cm} \mathrm{~s}^{-1}$ on the electrode surface do not damage the air electrode and result in more stable charging potentials due to the outtake of generated oxygen bubbles.

- The open set-up with passive air supply can lead to faster electrolyte leakage and to oxygen diffusion limitations at current densities $>50 \mathrm{~mA} \mathrm{~cm}^{-2}$. However, the build of the cell and the peripheral systems can be designed in a more compact way.

Long operation times of up to $800 \mathrm{~h}$ charge/discharge cycling at $50 \mathrm{~mA} \mathrm{~cm}_{\text {mean }}^{-2}$ were demonstrated for bifunctional air electrodes. For all tested electrodes, regardless of the operating conditions (flow, air supply, size), end-of-life was reached because of too low oxygen reduction potentials during discharge. As the ORR is very sensitive to the electrode structure due to the requirement of three-phase zones (gas/electrolyte/conductive catalyst), mechanical and chemical degradation effects are mainly apparent in the slowly decreasing discharge potentials. Improvements in long-term stability have to be tackled in this regard, either by manufacturing even more robust structures with more stable materials (e.g., substitute PTFE binder) or by keeping the anodic charging potentials during OER as low as possible.

Acknowledgements Open access funding provided by Graz University of Technology. Funding by the Austrian Federal Ministry of Transport, Innovation and Technology (BMVIT) and The Austrian Research Promotion Agency (FFG) through the program "e!MISSION.at Energieforschungsprogramm" (No. 848933) is gratefully acknowledged. We also want to thank our industry partners VARTA Micro Innovation $\mathrm{GmbH}$ (Austria) and RECAT (Germany). Nickel foam was generously provided by Alantum Europe GmbH, Germany.

Open Access This article is distributed under the terms of the Creative Commons Attribution 4.0 International License (http://creativeco mmons.org/licenses/by/4.0/), which permits unrestricted use, distribution, and reproduction in any medium, provided you give appropriate credit to the original author(s) and the source, provide a link to the Creative Commons license, and indicate if changes were made.

\section{References}

1. Chen H, Cong TN, Yang W, Tan C, Li Y, Ding Y (2009) Progress in electrical energy storage system: a critical review. Prog Nat Sci 19:291-312. https://doi.org/10.1016/j.pnsc.2008.07.014

2. Li X, Zhang H, Mai Z, Zhang H, Vankelecom I (2011) Ion exchange membranes for vanadium redox flow battery (VRB) applications. Energy Environ Sci 4:1147. https://doi.org/10.1039/ c0ee00770f

3. Alotto P, Guarnieri M, Moro F (2014) Redox flow batteries for the storage of renewable energy: a review. Renew Sustain Energy Rev 29:325-335. https://doi.org/10.1016/j.rser.2013.08.001

4. Leung PK, Li X, Ponce de León C, Berlouis L, Low CTJ, Walsh FC (2012) Progress in redox flow batteries, remaining challenges and their applications in energy storage. RSC Adv 2:1012510156. https://doi.org/10.1039/c2ra21342g

5. Dunn B, Kamath H, Tarascon J-M (2011) Electrical energy storage for the grid: a battery of choices. Science 334:928-935. https ://doi.org/10.1126/science.1212741

6. Perry ML, Weber AZ (2016) Advanced redox-flow batteries: a perspective. J Electrochem Soc 163:A5064-A5067. https://doi. org/10.1149/2.0101601jes

7. Arenas LF, Ponce de León C, Walsh FC (2017) Engineering aspects of the design, construction and performance of modular 
redox flow batteries for energy storage. J Energy Storage 11:119153. https://doi.org/10.1016/j.est.2017.02.007

8. Skyllas-Kazacos M, Chakrabarti MH, Hajimolana S, Mjalli FS, Saleem M (2011) Progress in flow battery research and development. J Electrochem Soc 158:R55. https://doi. org/10.1149/1.3599565

9. Li X, Ponce de Léon C, Walsh FC, Wills RGA, Pletcher D (2015) Zinc-based flow batteries for medium- and large-scale energy storage. In: Advances in batteries for medium and large-scale energy storage. Elsevier, New York, pp 293-315

10. Poullikkas A (2013) A comparative overview of large-scale battery systems for electricity storage. Renew Sustain Energy Rev 27:778-788. https://doi.org/10.1016/j.rser.2013.07.017

11. Pan J, Ji L, Sun Y, Wan P, Cheng J, Yang Y, Fan M (2009) Preliminary study of alkaline single flowing $\mathrm{Zn}-\mathrm{O}_{2}$ battery. Electrochem commun 11:2191-2194. https://doi.org/10.1016/j.eleco m.2009.09.028

12. Bockelmann M, Kunz U, Turek T (2016) Electrically rechargeable zinc-oxygen $\mathrm{fl}$ ow battery with high power density. Electrochem commun 69:24-27. https://doi.org/10.1016/j.elecom.2016.05.013

13. Xu M, Ivey DG, Xie Z, Qu W (2015) Rechargeable Zn-air batteries: progress in electrolyte development and cell configuration advancement. J Power Sources 283:358-371. https://doi. org/10.1016/j.jpowsour.2015.02.114

14. Davari E, Ivey DG (2018) Bifunctional electrocatalysts for Zn-air batteries. Sustain Energy Fuels 2:39-67. https://doi.org/10.1039/ C7SE00413C

15. Fu J, Cano ZP, Park MG, Yu A, Fowler M, Chen Z (2017) Electrically rechargeable zinc-air batteries: progress, challenges, and perspectives. Adv Mater 29:1604685. https://doi.org/10.1002/ adma.201604685

16. Pei P, Wang K, Ma Z (2014) Technologies for extending zinc-air battery's cyclelife: a review. Appl Energy 128:315-324. https:// doi.org/10.1016/j.apenergy.2014.04.095

17. POWAIR - Zinc-Air Flow Batteries for Electrical Power Distribution Networks. http://www.powair.eu/index.php. Accessed 17 Jan 2018

18. ZAESS - Zinc Air Energy Storage System. http://www.zaess.eu/. Accessed 17 Jan 2018

19. Caramia V, Bozzini B (2014) Materials science aspects of zinc-air batteries: a review. Mater Renew Sustain Energy 3:28. https://doi. org/10.1007/s40243-014-0028-3

20. Gilligan GE, Qu D (2015) Zinc-air and other types of metal-air batteries. Adv Battery Medium Large Scale Energy Storage. https ://doi.org/10.1016/B978-1-78242-013-2.00012-1

21. Zelger C, Laumen J, Laskos A, Gollas B (2016) Rota-Hull cell study on pulse current zinc electrodeposition from alkaline electrolytes. Electrochim Acta 213:208-216. https://doi.org/10.1016/j. electacta.2016.07.108

22. Wang K, Pei P, Ma Z, Chen H, Xu H, Chen D, Wang X (2015) Dendrite growth in the recharging process of zinc-air batteries. $\mathrm{J}$ Mater Chem A 3:22648-22655. https://doi.org/10.1039/C5TA0 $6366 \mathrm{C}$

23. Jörissen L (2006) Bifunctional oxygen/air electrodes. J Power Sources 155:23-32. https://doi.org/10.1016/j.jpows our.2005.07.038

24. Chen D, Chen C, Baiyee ZM, Shao Z, Ciucci F (2015) Nonstoichiometric oxides as low-cost and highly-efficient oxygen reduction/ evolution catalysts for low-temperature electrochemical devices. Chem Rev 115:9869-9921. https://doi.org/10.1021/acs.chemr ev.5b00073

25. Hong WT, Risch M, Stoerzinger KA, Grimaud A, Suntivich J, Shao-Horn Y (2015) Toward the rational design of non-precious transition metal oxides for oxygen electrocatalysis. Energy Environ Sci 8:1404-1427. https://doi.org/10.1039/C4EE03869J
26. Gupta S, Kellogg W, Xu H, Liu X, Cho J, Wu G (2016) Bifunctional perovskite oxide catalysts for oxygen reduction and evolution in alkaline media. Chem An Asian J 11:10-21. https://doi. org/10.1002/asia.201500640

27. Pichler B, Weinberger S, Reščec L, Grimmer I, Gebetsroither F, Bitschnau B, Hacker V (2017) Bifunctional electrode performance for zinc-air flow cells with pulse charging. Electrochim Acta 251:488-497. https://doi.org/10.1016/j.electacta.2017.08.128

28. Pletcher D, Li X, Price SWT, Russell AE, Sönmez T, Thompson $\mathrm{SJ}$ (2016) Comparison of the spinels $\mathrm{Co}_{3} \mathrm{O}_{4}$ and $\mathrm{NiCo}_{2} \mathrm{O}_{4}$ as bifunctional oxygen catalysts in alkaline media. Electrochim Acta 188:286-293. https://doi.org/10.1016/j.electacta.2015.10.020

29. Elumeeva K, Masa J, Sierau J, Tietz F, Muhler M, Schuhmann W (2016) Perovskite-based bifunctional electrocatalysts for oxygen evolution and oxygen reduction in alkaline electrolytes. Electrochim Acta 208:25-32. https://doi.org/10.1016/j. electacta.2016.05.010

30. Alegre C, Modica E, Aricò AS, Baglio V (2018) Bifunctional oxygen electrode based on a perovskite/carbon composite for electrochemical devices. J Electroanal Chem 808:412-419. https://doi.org/10.1016/j.jelechem.2017.06.023

31. Sumboja A, Ge X, Zheng G, Goh FWT, Hor TSA, Zong Y, Liu Z (2016) Durable rechargeable zinc-air batteries with neutral electrolyte and manganese oxide catalyst. J Power Sources 332:330-336. https://doi.org/10.1016/j.jpowsour.2016.09.142

32. Low CTJ, Roberts EPL, Walsh FC (2007) Numerical simulation of the current, potential and concentration distributions along the cathode of a rotating cylinder Hull cell. Electrochim Acta 52:3831-3840. https://doi.org/10.1016/j.electacta.2006.10.056

33. Wang RY, Kirk DW, Zhang GX (2006) Effects of deposition conditions on the morphology of zinc deposits from alkaline zincate solutions. J Electrochem Soc 153:C357-C364. https:// doi.org/10.1149/1.2186037

34. West AC, Matlosz M, Landolt D (1992) Primary current distribution in the Hull cell and related trapezoidal geometries. J Appl Electrochem 22:301-303. https://doi.org/10.1007/BF010 30192

35. Madore C, Matlosz M, Landolt D (1992) Experimental investigation of the primary and secondary current distribution in a rotating cylinder Hull cell. J Appl Electrochem 22:1155-1160. https://doi. org/10.1007/BF01297417

36. Gallaway JW, Desai D, Gaikwad A, Corredor C, Banerjee S, Steingart D (2010) A lateral microfluidic cell for imaging electrodeposited zinc near the shorting condition. J Electrochem Soc 157:A1279. https://doi.org/10.1149/1.3491355

37. Ito Y, Wei X, Desai D, Steingart D, Banerjee S (2012) An indicator of zinc morphology transition in fl owing alkaline electrolyte. J Power Sources 211:119-128. https://doi.org/10.1016/j.jpows our.2012.03.056

38. Shin S-H, Yun S-H, Moon S-H (2013) A review of current developments in non-aqueous redox flow batteries: characterization of their membranes for design perspective. RSC Adv 3:9095. https ://doi.org/10.1039/c3ra00115f

39. Ma H, Wang B, Fan Y, Hong W (2014) Development and characterization of an electrically rechargeable zinc-air battery stack. Energies 7:6549-6557. https://doi.org/10.3390/en7106549

40. Gu P, Zheng M, Zhao Q, Xiao X, Xue H, Pang H (2017) Rechargeable zinc - air batteries: a promising way to green energy. J Mater Chem A 2017:1-16. https://doi.org/10.1039/C7TA01693J

41. Li Y, Dai H (2014) Recent advances in zinc-air batteries. Chem Soc Rev 43:5257-5275. https://doi.org/10.1039/C4CS00015C

42. Prabu M, Ketpang K, Shanmugam S (2014) Hierarchical nanostructured $\mathrm{NiCO}_{2} \mathrm{O}_{4}$ as an efficient bifunctional non-precious metal catalyst for rechargeable zinc-air batteries. Nanoscale 6:3173. https://doi.org/10.1039/c3nr05835b 
43. Li PC, Chien YJ, Hu CC (2016) Novel configuration of bifunctional air electrodes for rechargeable zinc-air batteries. J Power Sources 313:37-45. https://doi.org/10.1016/j.jpows our.2016.02.063

44. Bogolowski N, Ngaleu O, Sakthivel M, Drillet JF (2017) Long-life bifunctional $\mathrm{BaSrCoFeO}_{3} / \mathrm{C}$ gas diffusion electrode. Carbon N Y 119:511-518. https://doi.org/10.1016/j.carbon.2017.04.051

45. Li PC, Hu CC, You TH, Chen PY (2017) Development and characterization of bi-functional air electrodes for rechargeable zincair batteries: effects of carbons. Carbon N Y 111:813-821. https ://doi.org/10.1016/j.carbon.2016.10.057

46. Li X, Pletcher D, Russell AE, Walsh FC, Wills RGA, Gorman SF, Price SWT, Thompson SJ (2013) A novel bifunctional oxygen GDE for alkaline secondary batteries. Electrochem Commun 34:228-230. https://doi.org/10.1016/j.elecom.2013.06.020

47. Lee DU, Choi JY, Feng K, Park HW, Chen Z (2014) Advanced extremely durable 3D bifunctional air electrodes for rechargeable zinc-air batteries. Adv Energy Mater. https://doi.org/10.1002/ aenm.201301389

48. Mainar R, Leonet A, Bengoechea O, Boyano M, de Meatza I, Kvasha I, Guerfi A, Alberto A, Blázquez J (2016) Alkaline aqueous electrolytes for secondary zinc-air batteries: an overview. Int J Energy Res 40:1032-1049. https://doi.org/10.1002/er.3499

49. Amunátegui B, Ibáñez A, Sierra M, Pérez M (2017) Electrochemical energy storage for renewable energy integration: zinc-air flow batteries. J Appl Electrochem 2017:1-11. https://doi.org/10.1007/ s10800-017-1133-7

50. Chalamala BR, Soundappan T, Fisher GR, Anstey MR, Viswanathan VV, Perry ML (2014) Redox flow batteries: an engineering perspective. Proc IEEE 102:1-24. https://doi.org/10.1109/JPROC .2014 .2320317

51. Lee J-S, Tai Kim S, Cao R, Choi N-S, Liu M, Lee KT, Cho J (2011) Metal-air batteries with high energy density: Li-air versus Zn-air. Adv Energy Mater 1:34-50. https://doi.org/10.1002/ aenm.201000010

52. Lapicque F, Belhadj M, Bonnet C, Pauchet J, Thomas Y (2016) A critical review on gas diffusion micro and macroporous layers degradations for improved membrane fuel cell durability. J Power Sources 336:40-53. https://doi.org/10.1016/j.jpows our.2016.10.037

\section{Affiliations}

\section{Birgit Pichler ${ }^{1}$ C B Bernhard S. Berner ${ }^{2} \cdot$ Nikolaus Rauch $^{1} \cdot$ Christian Zelger $^{2} \cdot$ Hans-Jürgen Pauling $^{3}$. Bernhard Gollas $^{2} \cdot$ Viktor Hacker $^{1}$}

Bernhard S. Berner

berner@student.tugraz.at

Nikolaus Rauch

nrauch@student.tugraz.at

Christian Zelger

christian.zelger@tugraz.at

Hans-Jürgen Pauling

hj.pauling@ recat.de

Bernhard Gollas

bernhard.gollas@tugraz.at
Viktor Hacker

viktor.hacker@tugraz.at

1 Institute of Chemical Engineering and Environmental Technology, Fuel Cell Group, Graz University of Technology, Inffeldgasse 25C, 8010 Graz, Austria

2 Institute for Chemistry and Technology of Materials, Graz University of Technology, Stremayrgasse 9, 8010 Graz, Austria

3 RECAT GmbH, Ochsenburger Straße 19, 75056 Sulzfeld, Germany 